\title{
John Chrysostom and the mission to the Goths: Rhetorical and ethical perspectives
}

\begin{abstract}
Author:
Chris L. de Wet ${ }^{1}$

Affiliation:

${ }^{1}$ Department of New

Testament and Early Christian

Studies, University of South

Africa, South Africa

Correspondence to:

Chris de Wet

Email:

chrisldw@gmail.com

Postal address:

PO Box 17585, Randhart,

Alberton 1457, South Africa

Dates:

Received: 09 Jan. 2012

Accepted: 06 Feb. 2012

Published: 29 June 2012

How to cite this article: De Wet, C.L., 2012, 'John Chrysostom and the mission to the Goths: Rhetorical and ethical perspectives', HTS Teologiese Studies/ Theological Studies 68(1), \#Art. 1220, 10 pages. http:// dx.doi.org/10.4102/hts v68i1.1220
\end{abstract}

C 2012. The Authors Licensee: AOSIS OpenJournals. This work is licensed under the Creative Commons Attribution License.
This study examines the role of John Chrysostom as bishop-missionary to the Goths in Constantinople. After Theodosius declared Nicene orthodoxy to be the only valid and legal faith, a potent programme to establish orthodoxy in Constantinople had begun, with bishops like Gregory Nazianzen and Nectarius promoting the cause. During and shortly after Chrysostom's arrival in Constantinople, most of the Arians were Goths, and Chrysostom became personally involved in their affairs. In the light of this, the study specifically looks at how Chrysostom constructs and negotiates barbarian identity, with special emphasis on the rhetorical and ethical dimensions of his involvement; with emphasis on the trajectories provided by Foucault and De Certeau for understanding rhetoric, ethics and identity. It is specially asked whether Chrysostom could escape the classical Graeco-Roman habitus of barbarism and the normativity of the free, male Roman body.

\section{A forgotten memory of stone in Istanbul}

Orhan Pamuk writes the following in his prolific yet pensive Istanbul (2004):

The city into which I was born was poorer, shabbier, and more isolated than it had ever been before in its two-thousand-year history. For me, it has always been a city of ruins and of end-of-empire melancholy. (p. 6)

I wish to commence this study from the Xerolophos in 18th-century Istanbul, where a similar monument resonated the melancholy of Istanbul, known in its youth as Constantinople. The column of Arcadius towered with an almost phallic ambience in the forum, a symbol of a once powerful empire long past. In this monument, time is transformed into space. Now demolished, the column was erected in 402/3 CE to commemorate the victory of the Arcadius over the Gothic uprising under the leadership of Gainas in $400 \mathrm{CE} .{ }^{1}$ The majestic column was only completed in 421 $\mathrm{CE}$, years after the death of Arcadius, with a statue of the latter on top. The column was destroyed sometime between the sixteenth and eighteenth centuries after being weakened by earthquakes and posing a threat of collapsing. Drawings made in 1574 and later give a full impression of the column from most angles. ${ }^{2}$ The column however, is on the one hand propagandistic with an emphasis on imperial policy, and on the other, also a cover-up of the actual events that took place in Constantinople in 400/1 CE - an imperial preferential history. The discursivity of this historiography, seen in Arcadius' column, is intriguing and crucial to the discussion of Chrysostom and the mission to the Goths. ${ }^{3}$ On the south side of the base of the column, the unity (concordia) of the two emperors Arcadius and Honorius are depicted in the second band from below, with two angelic figures over their heads, probably a Christian version of Victory (Nikê), which was also depicted on fourth century coins. It is similar to the Concordia Augustorum, aptly Christianized in a fragment of a homily by Severian of Gabala as the 'Peace of Christ'. ${ }^{4}$ The third band from below shows the chi-rho symbol, also presented by similar figures, framed on the sides and on the band above by weapons and armour, a typical motif probably already present in early Constantinian Christian art (Berefelt 1968:21-24; cf. also Peers 2001). On the eastern side of the base similar motifs are present. The frieze of the column shows the Goths leaving Constantinople in an imperial procession, with the typical representation of barbarian prisoners in Roman art and architecture (Nasrallah 2011:39-55). One section of the frieze depicts an angel and woman at the gate of the city, preventing the Goths from entering. Yet another frieze shows the Arcadian forces conquering the Goths, as well as their defeat and drowning at the Hellespont. ${ }^{5}$

1.For studies on the history and iconography of the column of Arcadius, see Kollwitz (1941:17); Becatti (1960:151-153), Grigg (1977); Liebeschuetz (1990:273-274); Kelly (2006:258-265).

2.The reliability of the drawings is uncertain. The sketches are found in Cambridge in the Trinity College Library and in the Bibliothèque Nationale in Paris. This paper uses the images reproduced in Grigg (1977:272) and Liebeschuetz (1990:315 [plates]).

3.For a detailed account of Gothic history and social development, see Wolfram and Dunlap (1990); Heather (1991, 1996).

4.In the fragment, Severian states: 'Just as the best painters often try to illustrate the unanimity of spirit by placing to the rear, near emperors or brothers, also magistrates, a Concordia in female form to illustrate the unanimity of spirit by placing to the rear, near that the divided bodies are one in mind, so the Peace of Christ [hē tou Christou eirēnē] unifies by embracing those who are divided!' The homily was probably preached on the feast of Epiphany in the age of Arcadius (Weyman 1894:626).

5.The ancient historical account of the building of the column is found in the ninth century work by Theophanes, Chronographia (Grigg 1977:469). 
The social memory of this monument is certainly fascinating in the sense that, although it is probably far from historically accurate$^{6}{ }^{6}$ it represents the history the Christian empire wanted to tell. It also illustrates the influence of imperial power discourses on historiography. It is an instance of the Christian empire 'speaking itself'. What is relevant to the study at hand is the fact that religion and politico-military activity are inseparable. The message of the column is a binary and stereotypical one: the uncivilised Gothic intruders, prone to violence, uprising and heresy, are expelled from the holy city by the divine imperial army. The two opposite identities, namely Gothic or barbarian and Roman or civilised are clearly discernible in the column by the very imperial iconography it displays. It also represents the victory of orthodoxy (antiArian) over heresy (Arian). In several locations the column shows the subjugated barbarian bodies, either fleeing or being killed during battle. But it is important to point out what the column does not show, or rather, represents incorrectly. The seemingly peaceful procession of the Goths from Constantinople was far from irenic. The Gothic expulsion from Constantinople was quite violent, with riots among non-Gothic Constantinopolitans against the Goths, along with military coercion rather being the main causes (Liebeschuetz 1990:273-278). The misrepresentation of the historical account intimates the controversial nature of the events in Constantinople in $400 \mathrm{CE}$, and renarrates the events with a positive light on the empire. It was a history the empire would rather choose to forget. The column of Arcadius is a tour de force of Christian rhetoric of imperiality. The Christian empire was forged not only on military victory, but more so, on rhetoric and the column aims to suppress Pamuk's 'end-of-empire melancholy' already present, in my opinion, in the fourth century.

It is this history, and more importantly, this rhetoric, that serves as backdrop for the discussion at hand. And as it can be seen, the milieu was one of religious, social and political instability. During the time of these events and a few years before, John Chrysostom was the bishop of Constantinople.? He in fact played an important role in the events described above pertaining to Gainas and to the situation of the Goths in Constantinople in general. It is this second role which is the concern of this article. Chrysostom is well known for his missionary activity (Batiffol 1899:566-572; Sibiescu 1973:375388 ) and is quite unique in his status as bishop-missionary. What rhetorical and ethical discursivities may be delineated from Chrysostom's missionary work among the Goths of Constantinople, and how can they aid in understanding mission in late antiquity? A preliminary discussion of the socio-religious situation in Constantinople shortly before the arrival of Chrysostom is the place where this investigation will begin.

\section{An Arian city}

In the first years after becoming emperor in $379 \mathrm{CE}$, Theodosius I initiated an extensive programme of imposing

6.There are three other versions of the Gainas affair namely Zosimus-Eunapius, Sozomen-Socrates and Synesius (Liebeschuetz 1990:111).

7.For biographical studies on Chrysostom, see especially Kelly (1995); Mayer and Allen (1999).
Nicene orthodoxy in Constantinople. The first move of this was to annul the edict of tolerance issued earlier in $379 \mathrm{CE}^{8}$ and making heresy illegal in the East. ${ }^{9}$ Liebeschuetz affirms that this was done with special zeal by Theodosius and Ambrose of Milan, and probably less so by Gratian, who initiated the edict. The unity of the church had become an imperial priority.

This however, would put Theodosius in a difficult position with the Arians, who were in the majority in Constantinople. In order to succeed, Theodosius first had to unify the numerous orthodox factions in the East. The two main factions were those represented by Peter of Alexandria (Egypt) and Damasus (Rome), against that of Meletius (Syria and Asia Minor). In $380 \mathrm{CE}$, Theodosius ruled in favour of Peter of Alexandria and Damasus. Both Socrates and Sozomen report similar divisions among the Arians. The first attempt toward orthodox missionary activity in Constantinople was made by Gregory Nazianzen in 379 CE. Liebeschuetz (1990) states:

Gregory was installed in a private house where he held services in a chapel dedicated to St Anastasia, the name of the patron saint, 'Resurrection', representing a programme: the revival of orthodoxy. (p. 159)

The number of orthodox Christians was low, as Gregory himself admits:

This was my field, when it was small and poor, unworthy not only of God ... I found Israel like a fig tree in the wilderness, and like one or two ripe grapes in an unripe cluster (Isaiah 65:8) ... Such was its former poverty and dejection. (Orat. 42: par. 4 [Supremum Vale]

The agricultural metaphor seen above illustrates how few and scattered the orthodox Christians were in Constantinople. Gregory's success was limited and he was under severe persecution from the Arians. He was attacked in his own chapel during a baptism ceremony and just survived an assassination attempt. ${ }^{10}$ Public demonstrations against Gregory were common. With imperial aid, Gregory's involvement did result in some growth amongst the orthodox Christians. In $381 \mathrm{CE}$, Gregory resigned from his see in Constantinople, after a very difficult reign. He had no control of the synod of bishops, still had strong Arian opposition in Constantinople, and the growth of orthodoxy was steady but too slow (Liebeschuetz 1990:163). He was also the victim of a conspiracy under Damasus and the bishop of Alexandria. After Gregory's resignation, Nectarius was chosen for the see of Constantinople. ${ }^{11}$ As the months passed, orthodoxy gained a stronger footing in the city. One setback was in 388 $\mathrm{CE}$ when the palace of the bishop was burnt down after a series of riots. ${ }^{12}$

What was the deciding factor in the slow success of orthodoxy in Constantinople? Having started out as a small

8.Socrates, Hist. Eccl. 5.2; Sozomen, Hist. Eccl. 7.1.

9.C.Th. 16.5: par. 5: 'All heresies are forbidden by both divine and imperial laws and shall forever cease. If any profane man by his punishable teachings should weaken the concept of God, he shall have the right to know such noxious doctrines only for himself but shall not reveal them to others to their hurt' (transl. Peters 1980:45).

10.De Vita Sua 1402-1406.

11.Socrates, Hist. Eccl. 5: par. 8; Sozomen, Hist. Eccl. 7: par. 8.

12.Socrates, Hist. Eccl. 5: par. 13. 
missionary endeavour by Gregory, the imperial involvement behind this was probably the reason for success, without which orthodoxy would not have eventually prevailed. Along with the numerous laws issued in favour of Nicene orthodoxy, it was the confiscation of Arian buildings that made the difference at grass-roots level. This happened on 24 November 380 CE after the Arian bishop Demophilus was expelled from the church of St. Sophia, having refused to sign an orthodox declaration of the emperor, who was in Constantinople. All other Arian priests were also expelled from their church buildings (Liebeschuetz 1990:159). ${ }^{13}$ This was an extremely tense and unstable situation for Gregory and the emperor, who had to subdue the populace with soldiers. All Arian congregations received orthodox priests (Thompson 1966:133-135). Theodosius' strategy was successful in the long-term. A second important move made by Theodosius was when the bones of the martyr Paul of Constantinople were returned to the city. ${ }^{14}$ The history behind the death of the martyr is unclear, but Athanasius of Alexandria states that he was strangled by the Arians. ${ }^{15}$ The bones were buried in the building that was erected by Paul's Arian counterpart, Macedonius. The former Arian building now became a martyrium for Paul of Constantinople. This reaffirmation of sacred orthodox space was a powerful strategy against the Arians. It illustrates that orthodox authorities were more concerned, in missionary terms, with the evangelisation of space rather than people. The strengthening of the orthodox cult of the saints was crucial to the imperial success, a success that Chrysostom would continue to build on and develop. By returning the remains of Paul of Constantinople (Sozomen even declares that some people believed it was the bones of Paul the apostle) (Liebeschuetz 1990:164), the mystical praesentia and potentia of the orthodox martyr would be present (Brown 1981:106114). It is now no longer simply a matter of land and building seizure, but rather imposing divine orthodox power on the city. This is further proven by the orthodox acceptance of the tombs of Martyrius and Marcian, two of Paul's clerics, also executed, of whom it was reported that many miracles and divine spectacles took place. Chrysostom would later even build a church at this location. Theodosius also brought the head of John the Baptist into Constantinople, which was later housed in a church building just outside the city. ${ }^{16}$ The most important point is that people believed that the potentia of the martyrs was orthodox, and thus affirmed its importance. It also acts as a marker of the divine support for and authority of Theodosius. With the confiscation of buildings, it would be very difficult for the Arians to match this.

Theodosius' strategy of expelling Arian priests from their church buildings, the strengthening of the orthodox cult of the saints, and consecrating Gregory (and later, Nectarius) as

13.Sozomen, Hist. Eccl. 7: par. 5-7; Socrates, Hist. Eccl. 5: par. 6-7; Philostorgius, Hist Eccl. 9: par. 19; Theodoret, Hist. Eccl. 5: par. 8.

14.Sozomen, Hist. Eccl. 7: par. 10; Liebeschuetz (1990:164).

15.Studies on Paul of Constantinople and other martyrs and saints of the city include Telfer (1950:30-92); Dagron (1974); Magdalino (1996).

16.As in the case of many relics in late antiquity, it was probably not the actual head (Mango 1978:115-122). The relic is currently housed at the Topkapi Palacemuseum in Istanbul. bishop, was very effective in forcing orthodoxy on the Arian Constantinopolitans. Despite all this, Arianism only slowly dissipated from Constantinople, and often experienced short but potent revivals (Liebeschuetz 1990:160-161; Thompson 1966:133). At this point it is important to establish that mission in late antiquity was a complex dynamic between imperial authority, the creeds and the bishops.

\section{John Chrysostom as bishop- missionary}

John Chrysostom was installed as bishop of Constantinople in $381 \mathrm{CE}$ after the sudden death of Nectarius. Chrysostom's biographer Palladius states that Chrysostom's transfer from Antioch to Constantinople was secret in order to avoid a possible uprising in the city. Asterius, the Count of the East (comes Orientis) met Chrysostom at the Romanesian Gate of Antioch and the two made for Constantinople. ${ }^{17}$ Once in Constantinople, Chrysostom followed a different and less forceful approach to Arianism (Kelly 1995:142-143). Although he did preach a series of sermons against some extreme Arians called the Anomoeans, ${ }^{18}$ most of his sermons were rather focussed on Christian morality. Many Goths, however, were Anomoeans (Kelly 1995:142). Chrysostom was a renowned social critic, and especially interested in establishing a popular type of asceticism accessible to citydwellers. The regularity of the Christian sermon proved to be a deciding factor in the Christianization of daily life in late antiquity..$^{19}$ His indirect approach to Arianism seems to have been successful, and at this point, most Arians in the city were members of the Gothic community.

It is in this instance that we see Chrysostom's surprising missionary zeal. As bishop-missionary, he had a very special concern for the Goths of Constantinople. Most importantly, Chrysostom made a church available to the Goths for services, although these services would be orthodox. ${ }^{20}$ The building used was a church situated next to the church of Paul of Constantinople, possibly the church at the site of the martyrs Martyrius and Marcian mentioned above (Liebeschuetz 1990:168-170). Chrysostom understood the importance of spatiality for missionary work in late antiquity. ${ }^{21}$ The building was in a prime location, near the martyrium of Paul. It seems plausible that the Goths could have associated with the cult of the saints in Christianity in the light of the roots of Gothic tribal religion (Schwarcz 1999:447-472). Having set aside a building for the Arian Goths, Chrysostom could conveniently begin his missionary work among the Goths. Theodoret also reports that Chrysostom conducted missionary work outside of Constantinople, amongst nomadic Goths along

17.Palladius, Dial. 5 (Mayer \& Allen 1999:8).

18.Contra Anomaeos Hom. 1-10.

19.The effects of the late antique Christian homiletics in society have been examined at length (for instance Maxwell 2006:144-168; Mayer 2008:565-183; Liebeschuetz 2011:1-42).

20.Theodoret, Hist. Eccl. 5: par. 30 (Liebeschuetz 1990:169-170; Kelly 1995:143). There has been some contestation regarding the use of the church building referred to, since Synesius of Crete states that the building was also used by Goths for Arian services (Stanfill 2011).

21.For a related study on spatiality in John Chrysostom's Adversus Judaeos, see Shepardson (2007:483-516) 
the Danube. ${ }^{22}$ Most of the Goths were settled south of the Danube after 376 CE. The condition was that they had to convert to Arian Christianity, the faith followed by Valens (Heather 1986:289-318). Now they had to convert once again. Chrysostom also aided in the establishment of a Gothic monastic community. ${ }^{23}$ Thompson states that he consecrated a bishop for the Goths in Crimea, a certain Unila (Thompson 1966:134; see also Wolfram \& Dunlap 1990:78). He also provided Gothic-speaking priests to those in the church in Constantinople, gave them a building to worship in and also provided them with leadership.

It needs to be made clear that this type of missionary fervour was rare among the priests and bishops of the empire. However, there were certainly numerous Goths in the city, many Goths such as Gainas, held honourable positions in the army, and many were by this time Roman citizens (Liebeschuetz 1990:7-26). The outreach to the Goths within the geography of his see may have been a strategic political move, so that Chrysostom could positively influence the non-Gothic and Gothic citizens of the city. There was one serious incident in early $400 \mathrm{CE}$ in which Gainas requested a church building for the Arian Goths for the purpose of Arian services, which was vehemently opposed by Chrysostom. This may have caused some bad blood between Chrysostom and some Goths, and also resulted in uprisings in the city (Wolfram \& Dunlap 1990:149).

We will now take a closer look at Chrysostom's missionary work among the Goths, starting by delineating the rhetorical dimensions of his involvement. This section is mainly concerned with how Chrysostom constructs the identity of the 'evangelisible' barbarian. How does Chrysostom then construct and negotiate barbarian identity?

\section{John Chrysostom and the rhetoric of barbarian identity}

At first glance it seems that Chrysostom may be described as an ardent barbarophile. But could he move beyond the prejudice of the classical Graeco-Roman habitus of barbarians and barbarism? We have already seen in the history displayed on the column of Arcadius that classical Roman motifs of the barbarian image were still quite prevalent in the fifth century. This prejudice was probably even more aggravated by the Gainas event. But how did the Romans see barbarians? The name in itself is already a sign of 'othering' those outside the cultural, racial and even geographical borders of the empire. ${ }^{24}$ The very idea of the 'barbarian' is a construction, and also I argue, a non-existent conjecture. ${ }^{25}$ The grouping of outsiders under one appellation seeks to undermine the identity of the outsiders. It also centralises Roman identity, since it then

22.Theodoret, Hist. Eccl. 5: par. 30-31.

23.John Chrysostom, Ep. 14: par. 5; 207.

24 For studies on the theory and rhetoric of 'othering', see De Certeau (1986); Riggins (1997:1-30): Canales (2000:16-31): Van Houtum and Van Naerssen (2002:125136); Bowman (2003:500-501); Gruen (2011).

25. For more clarification of the conception of barbarian identity in the Graeco-Roman world, see Dauge (1981); Hall (1991); Heather (1999: 234-258); Woolf (2011:3258); Mathisen (2011:17-32). implies that Roman identity is the only valid identity. It is much more convenient just to speak of 'barbarians', despite the various identities, for instance the Visigoths, Ostrogoths, Slavs, Huns, Alamanni and Franks, et cetera. The fact that the homeland of the barbarians was outside, on the 'fringes' of the known world attributed to their alienation amongst Romans (Hedeager 1987:125-140).

The reputation of the Goths in late antiquity was ambiguous. Originating from the area northwest of the Black Sea, the Goths often found themselves at war with the Romans especially in the third and fourth centuries. After signing a peace treaty with Constantine, many Goths were recruited into the Roman army. A period of relative peace ensued up to 367 CE. From 367-369 CE wars plagued the relations between Romans and Goths once again, but ended as quickly as they had started (Liebeschuetz 1990:7-31; Heather 1999:234-239). During this period of war an upsurge of anti-Gothic rhetoric was present and the old views of barbarism were revived. One late ancient historian, Ammianus, was especially negative about the Goths and barbarians in general, by likening them to animals (Wiedemann 1986:135-154). Again, an imaginary dichotomy was set up to discern Romans from 'barbarians', despite the intermingling of the two during and after Constantine's era of peace. This dichotomy would ensue for decades up to and after the Gainas affair. One potent way of promoting this type of anti-barbarian rhetoric was the affirmation of the stereotype in the context of public entertainment - the games. Peter Heather's (1999; see also Rohrbacher 2002:230-235) observation on the topic is applicable here:

It was thus the fate of many outsiders - 'barbarians' as the Romans would call them - to die for the empire, both so that its frontiers could be preserved intact, and to reinforce the ideologies which gave the empire internal coherence. (p. 235)

It is this latter statement that I would like to explore. I will argue that the 'barbarian body' was a primary vehicle to enforce the classical ideology of Roman-ness, primarily in the interest of the educated and wealthy elite. It must however be remembered that the habitus of barbarism was borrowed from the Greeks. Gruen (2011) states:

Roman traditions claimed no purity of lineage. Distinctiveness of blood or heritage never took hold as part of Roman selfconception. Indeed, the Romans lacked a term for non-Roman. They had to borrow the Greek notion of 'barbarian,' a particular irony since it signified in origin non-Greek speakers - a category into which the Romans themselves fell. (p. 345)

The ideal Roman body was characterised by two important features: manliness and impenetrability. ${ }^{26}$ In the first instance, masculinity was characterised by the ability to dominate others, especially slaves and women and, in military terms, enemies and outsiders. This domination is therefore manifested in mastery and practiced from a site of social superiority in terms of status and ethnicity. If mastery is what 'makes a man', then mastering one's desires and disciplining one's thoughts are just as important

26.These concepts are delineated by Walters (1997:29-46), and for a discussion of how imperial power and rhetoric influences sexuality and the body, see Mattingly (2011:94-124). 
as having control over one's wife, children and slaves. It is in this instance that Roman historians choose to discern the barbarian body (Heather 1999:234-237). Three years after Chrysostom was elected as bishop of Constantinople, Themistius was appointed as prefect of the same city by Theodosius in $384 \mathrm{CE}$. Themistius was not a Christian, but he enjoyed much favour with the emperor. He was also an avid political propagandist and used this to a great extent in his philosophy and rhetoric - especially against barbarians (Penella 2000:1-50). Themistius (quoted in Heather 1999) states:

There is in each of us a barbarian tribe, extremely overbearing and intractable - I mean temper and those insatiable desires, which stand opposed to rationality as Scythians and Germans do to the Romans. (p. 236)

The passions of the body should yield under the dynamics of the intellect, a typical Stoic concept. The metaphor used by Themistius is indicative of an ideology among Romans and Greeks that barbarians are uneducated and not in control of their bodily passions. The absence of the ability to speak Greek and Latin worsened the situation. The Herodotean image of the babble of barbarian language possibly serves as the etymological impetus for the word barbaros, most likely an instance of onomatopoeia. ${ }^{27}$ The sounds of the barbarian serve as markers of distinction and otherness. The barbarian body has a voice, but no language, only babble. Regarding voices without language, De Certeau (1984:163-164) states: '... these sounds waiting for a language, seem to certify, by a "disorder" secretly referred to an unknown order, that there is something else, something other.' It is not only the absence of an intelligible imperial language, but also the absence of oratory skills that inform the Roman image of the barbarian. Libanius, a professor of rhetoric in Antioch, and Chrysostom's teacher, notes that if oratory should become extinct, the Romans would resemble the barbarians. ${ }^{28}$ It is only with classical education and studying the language of the empire and accompanying oratory, that barbarians can master their bodies and validate their identity. Furthermore, the inferiority of the barbarian body was embedded in ancient natural (pseudo-) science. Romans understood themselves to be naturally superior. The early Roman historian Livy denigrated the naked exhibitionism of the barbarians, whilest Ammianus calls barbarians (specifically Persians) oversexed. Other instances of invective include ritual prostitution, incest and gluttony (Heather 1999:236-237; Richlin 2009:327-353). Such barbarians were therefore not truly viri since they were not able to master their bodies. The logical inference of this is that they were not able to bring their larger social body into submission under the written law - they were thus lawless, whilst the Romans had social order. 'Thus for Romans the rule of written law - encapsulated, in the late imperial concept of civilitas - was the great distinguishing feature of their society,' writes Heather (1999:237). The links between barbarians and excessive violence was also very common in late antiquity - in fact, the construction of

27.For a discussion of this complex issue, see Munson (2005); for some interesting studies related to this from a more contemporary context, see Lianeri and Zajko (2009).

28.Libanius, Ep. 372: par. 7 the barbarian image and the conceptualisations of violence went hand in hand in the Roman world (Pohl 2006:15-26; Mathisen 2006:27-36). In the eyes of the Roman insiders, the barbarian outsiders lacked a classical education, could not control their bodily lusts, and did not abide by the precepts of a law-abiding social body. The rise of Christendom did not prove to be ameliorative. Accusations of faithlessness and impurity were commonplace, and the fact that most Goths, in Constantinople at least, were Arian did not help either (Heather 1999:237).

The second crucial trait of the Roman body was its impenetrability. The Roman male body is one that penetrates and dominates. The opposite of this is the female quality of being passive, submissive and penetrated (Parker 1997:47-65) - also applicable to barbarians, who should be forced into submission. On the column of Arcadius, this rhetoric is present, with numerous scenes of naked and half-naked Goths at the feet of the Roman soldiers who stabbed (penetrated) them with their spears or swords. It is also commonly depicted on Roman coins and sculptures (Calo Levi 1952). The numerous executions of barbarians in the arenas around the Roman Empire reverberate the same social language of subordination and domination. Themistius compares the battle of the Romans against the barbarians with the gigantomachia, the mythological depiction of the universal battle of the forces of order against those of chaos (Daly 1972:378). The reality is that this rhetoric was difficult to maintain. Even Themistius was aware of the importance of winning the approval of the barbarians, thus within his antibarbarian polemic, he also included a rhetoric of assimilation. If the barbarians would become Roman the problem would be solved. He also urged the Roman government to approach the barbarians with philanthropia. Pavan goes so far as to say that Themistius was well aware of the barbarian strength and that although they were culturally inferior, their physical and material strength had become a threat (Pavan 1964:18-19). In my opinion, Themistius was probably not a misobarbaros, fearing the brute force of the surrounding barbarian tribes. To a more or lesser extent, Themistius resembles Porphyry of Tyre. Porphyry was certainly much more accommodating regarding 'barbarian wisdom', but still exhibited a subtle ethnographic grammar of difference between the Greeks and the barbarians (Clark 1999:112-132; Schott 2008:52-78). This same sense of difference is more explicitly evident in Themistius, who is sympathetic to the barbarians, but only insofar as they are not Roman.

Would Chrysostom be able to escape the classical Roman habitus of barbarian identity within his missionary effort? We have one sermon of Chrysostom in which he directly addressed the Goths. ${ }^{29}$ There were probably many more since he was personally involved with the Gothic congregation in Constantinople. According to Thompson, Chrysostom often preached there with the aid of an interpreter (Thompson 1966:133-134). In this sermon, Chrysostom sets out to praise the Goths and barbarians in general, for their role

29.John Chrysostom, Homilia habita postquam presbyter Gothus; see Battifol (1899:566-572); Sibiescu (1973:375-388). 
in the expansion of Christianity. In fact, Chrysostom starts with references to Abraham, and also Moses and the Magi present at the birth of Jesus (the Magi get much attention in the sermon). The leitmotiv of the sermon is that within the church, there is no difference between Greek (or Roman) and barbarian (referring to Col 3:11). He alludes to the importance of the Gothic Bible in spreading Christianity amongst the Goths. He also states that it was permitted for Goths to stand up and speak in church. Thus, Chrysostom seems to hold a positive view of barbarians in his sermon. The problem of language does not appear to bother him as much as it did his teacher Libanius (although I believe that this may have been a very difficult compromise for Chrysostom, but this view remains utterly speculative). The influence of the Gothic Bible among Gothic Christians also implies recognition of 'voice' by Chrysostom. This is seen in his exposition of 1 Corinthians 14:11, in which barbarian languages are equated with Latin in terms of their ability to pray to the same God..$^{30}$ He also admonishes them to study the scriptures whenever they have the opportunity. Notwithstanding this, the sermon is still quite paternalistic and patronising. In a reference to Isaiah 65:25, which reads 'the wolf and the lamb will feed together', Chrysostom states that even the most barbarous of barbarians 'were standing together with the sheep of the church, with a common pasture and one fold, and the same table set before all alike' (transl. Kelly 1995:143). This rhetoric of differentiation and cultural hegemony occurs frequently in the sermon. It is also present in other homilies preached by Chrysostom. In one homily he states: 'For in truth God had brought and put into his hands not those who inhabited the country of the Romans only, but also all the barbarians, both land and sea,' and thereafter quotes Romans 1:13-14. ${ }^{31}$

We thus see a very similar pattern with Chrysostom as with Themistius. Both are unable to think outside the dichotomy between Roman and barbarian, and both are convinced that to be a barbarian still assumes not being civilised (Clark 2011:42), but they do not despise the barbarians. For Themistius, the 'cure' for being barbarian is to become Roman, and for Chrysostom the cure would be to become an orthodox Christian. The reasons for their sympathy towards the barbarians, amongst whom they live, seem unclear, but it is possible that both realised the growing influence and strength of the barbarian presence inside and outside the empire. Barbarian integration was a complex issue (Pohl 1997:1-12; Durliat 1997:153-180). Chrysostom's mission to the Goths may have been a political or a religious strategy. This is especially seen in his close surveillance of the election of the Gothic bishop of Crimea (Wolfram \& Dunlap 1990:78). Although Chrysostom had much trust and influence in the Gothic community of Constantinople, the historian Theodoret mentions that the majority of Goths were still Arian after Chrysostom's Episcopate. ${ }^{32}$

30.John Chrysostom, Hom. in Ep. I Cor. 35: par. 4; see also the discussion in: González Blanco (1978:263-299).

31.John Chrysostom, Prof. Evang. 4; transl. NPNF.

32.Theodoret, Hist. Eccl. 5: par. 30
Despite the views of influential figures such as Chrysostom and Themistius, an aura of instability was still present in Constantinople and the surrounding areas. The situation became quite serious in the mid 390s with the events surrounding Gainas and Eutropius. ${ }^{33}$ Chrysostom played an important role here, and managed to wield some influence in order to save some of the hostages held by Gainas, and even sheltered Eutropius himself for a short period. A stressful period for Chrysostom indeed, since it was also the beginning of the controversy about Theophilus, the bishop of Alexandria, which would eventually lead to Chrysostom's exile (Mayer \& Allen 1999:9).

\section{Ethical considerations on Chrysostom's missionary activity}

Mission in late antiquity was a complex strategic discourse. It is complex because, as this study has illustrated, mission takes place at the intersection of political, social, religious and cultural discursivities. It is strategic since it functions within the wider totalising discourse of imperiality. Contrary to the oft-supposed bi-lateral nature of mission as 'one being sent', and 'those who receive "the word"', mission in late antiquity is more aptly understood as a complex network of social relations and power dynamics. The common motifs of centrifugality and cetripetality (Bosch 1992:207) do not seem to hold fast, which render traditional models of understanding mission ambiguous and even opaque in the context of late antiquity. Chrysostom's context does not simplify the question, since his relationship as 'missionary' with the Goths is in itself ambiguous. What is the ethical dimension of Chrysostom's missionary activity among the Goths in Constantinople? ${ }^{34}$

Throughout this study, the problem of the construction of identity constantly arises. The understanding of the self or the subject and also the discursive other becomes a crucial ethical aspect of mission in late antiquity, one that I would like to address in this instance. In the previous section, the rhetorical aspects of this process have been delineated. But how does this impact on an ethics of the self ${ }^{35}$ and the other ${ }^{36}$ in the context of mission as a complex discourse in late antiquity? The logical point of departure for this discussion should be the legislation Theodosius reinstated that Nicene orthodoxy, thus Theodosian Catholicism, was the only valid form of religious observance and expression. This created a context for 'mission', since it immediately creates opposites and, as I will argue below, categories for normalcy and abnormalcy. In the formalisation and application of this law a potent somatography is present. I take the lead from Michel de Certeau (1984) in this instance:

There is no law that is not inscribed on our bodies. Every law has a hold on the body. The very idea of an individual that can be isolated from the group was established along with necessity,

33.For a full discussion of the controversy of Eutropius and Chrysostom's role therein, see Kelly (1995:145-162).

34.As will be seen, I rely much on the work of Foucault and De Certeau for understanding mission and ethics in Chrysostom and late antiquity.

35.Regarding an ethics of the self, see Foucault (1986, 1988:16-49, 2010).

36.For a theory of the 'other', or heterology, see De Certeau (1986). 
in penal justice, of having a body that could be marked by punishment...[L]aw 'takes hold of' bodies in order to make them its text ... it transforms them into tables of the law, into living tableaux of rules and customs, into actors in the drama organized by social order. (p. 140)

It is then the somatography of identity of Theodosius' law which is the impetus for this ethical investigation. It is this that made it possible for Chrysostom to perform missionary work among the Goths in Constantinople. Notwithstanding its numerous political, religious and economic consequences, the Theodosian legislation had important psychosocial consequences. As De Certeau stated above, it creates the necessity for a body to be marked as being heretical, and thus abnormal. Chrysostom's Constantinopolitan Goths have a double serving of abnormalcy, since they are Arians ('heretics') and barbarians. The implication of Theodosius' law counts against them, as well as the classical Roman habitus of barbarism, which was alive and well in fourth century Constantinople. The issue of barbarians is more than just one of nomenclature. They were the targets of constant xenophobic 'othering'. Our ethical investigation therefore calls us to look at the heterologies of barbarism and heretics in late antiquity, especially in the context of Chrysostom. We have already viewed the rhetorical dimensions of barbarism in classical and late antiquity, as well as its Chrysostomian context. But what are the ethical implications? Since the Goths, as the new evangelisible abnormal other, are both barbarian and heretical, two psycho-ethical heterologies become evident. First, in the notion of the Goth as barbarian, we find the concept of the human monster. In his discussion of the 'abnormals', Michel Foucault (1994:50-53) lists this element, along with the next one I shall mention as well as a third (the onanist), which is not applicable to this study. In the previous discussion of the rhetoricity of barbarism, we saw that late Roman historians often referred to barbarians in animalistic terms. They were thus naturally and socioethically inferior. The rhetorical strategies of naturalisation and animalisation are very powerful. Thomas Wiedemann (1986) illustrated this aspect in his essay 'Between men and beasts: barbarians in Ammianus Marcellinus'. The inability to control the bodily desires, tendency toward gluttony and sexual promiscuity and even oversexing were indicative of this. Furthermore, barbarians were accused of being faithless, untrustworthy and prone to social disorder (inability to control the social body) (Heather 1999:234-248). There were many types of animals Ammianus used as metaphors for barbarians, including vipers, dogs, vultures, wounded lions and bulls. Like animals, barbarians are incapable of selfmastery, and thus incapable of virtue. Wiedemann (1986:198200) highlights the notion of the wild animal, the beast of prey, the predatory carnivore as a common metaphor. Ammianus depicts the barbarian as a human-animal due to their inability to reason, practice virtue and maintain social order. In antiquity, the same stereotype was used for slaves. Although certainly less suspicious of barbarians than Ammianus, Chrysostom's sermon to the Goths, is not devoid of this imagery. Even the most ferocious of barbarians attended the church service, according to Chrysostom. He continues to compare the Goths with wolves (the others with sheep). The metaphor of the wolf assumes the same principles of the Ammianian 'wild-beast', which is dangerous, blood thirsty and ferocious. Even these barbarians are at home in Chrysostom's pasture. The presence of the barbarian, the big bad wolf, in the church seems to imply a near eschatological harmony. Foucault (1994), writing on the human monster, states that it is:
... an ancient notion whose frame of reference is law. A juridicial notion, then, but in the broad sense, as it referred not only to social laws but to natural laws as well; the monster's field of appearance is a juridico-biological domain. The figure of the half-human, half-animal being ..., of double individualities ..., in turn, represented that double violation; what makes a monster a monster is not just its exceptionality relative to the species form; it is the disturbance it brings to juridicial regularities (whether it is a question of marriage laws, canons of baptism or rules of inheritance). (p. 51)

These last three issues mentioned by Foucault all had special rules and circumstances to barbarians who, for instance as we will see below, were not simply allowed to marry a Roman citizen. The construction of the barbarian as human monster is seated in ancient natural 'science' as well as socio-juridical discourse. ${ }^{37}$ Thus, the monster should be kept separate, and confined to the periphery (something Foucault has also demonstrated in his Madness and Civilization 1961). In Chrysostom's context, we see this process in its extreme form with the expulsion of Goths from Constantinople it was well captured in the column of Arcadius. Mission to the 'savages' and barbarians was more crucial then the issues of security and territory. This ethical issue was especially evident in Chrysostom's context. It was seen in the migration and settlement of barbarians in the Roman Empire in the wider sense, but in a more narrow focus, by the use of church buildings, martyria and other sacred spaces in Constantinople. I will not repeat these issues again. The strict regulation of barbarian bodies (in principle and law at least, much less in reality) within imperial spaces was a key priority. Mission can therefore been seen in this instance as an apparatus of security and technology of governmentality. It was also supposed to help late ancient Romans with population issues. Other similar apparatuses were barbarian recruitment into the army, trade relations with barbarians, and intermarriage with Roman citizens. A law from the Codex Theodosianus states:

For none of the provincials, of any rank or status, may there be a marriage with a barbarian wife, nor may any provincial woman marry any of the gentiles. But if any relations by marriage arise ...[they] shall be punished capitally. (C. Th. 3.14: par. 1; trans. Mathisen [2009:140-55])

Mission, and the development of the pastorate was, according to Foucault (2007:115-162), a defining event in Western perceptions of political power and governmentality. When the monster, the animalistic barbarian, is within the spatial boundaries of the empire, like a wolf among the sheep, it needs to be strictly regulated, controlled and most importantly, trained and corrected.

37. For a very relevant study on the construction of the barbarian and its implications in modern history, see Wood (2008:61-81). 
This brings me to the second heterology - the individual who should be corrected. This point is especially relevant to the Arian aspect of the Goths' identity. Chrysostom, as late ancient bishop-missionary, now becomes a psychagogue someone in the business of shaping the heretical soul into one that is orthodox (Maxwell 2006:151). It implies giving the individual both voice and language, as we have seen. Chrysostom provided the Goths with Gothic priests and praised them for having the scriptures in their own language, referring to the Gothic Bible, which was the primary scriptural apparatus for Gothic Christians (Thompson 1966:133-135). He even allowed them to speak in church, an issue that is mostly discussed in gender terms, but not always in ethnocultural terms as in this case. Barbarians, it seems, were not always allowed to speak in church, or perhaps it was frowned upon if they did. Not only did they get voice (that is, intelligible leadership) and language, but Chrysostom also gives them a precious gift - namely parrêsia. Foucault (2010:61) discerns between a performative utterance, which is 'ordered in advance, ... codified,' and parrêsia, in which 'the irruption of the true discourse determines an open situation, or rather opens the situation and makes possible effects which are, precisely, not known.' It shows some trust by Chrysostom, especially since the general feeling of barbarians in Roman cities was suspicious rather than tolerant and accommodating. If one gives someone the power of parrêsia, the more necessary the framework for training and correcting such parrhesiastic bodies becomes. Hence we see, along with a structured congregation, where teaching and preaching takes place, Chrysostom also supported monastic Goths in the peripheries of the city, and even within a wider geographical scope in his see. It is no surprise that in general, missionary activity also resulted in the building of hospitals, schools, monasteries and churches. All these institutions are based on surveillance and correction. The Gothic Christian activity in Constantinople was a closely watched drama, especially by Chrysostom himself and his aides and superiors. He was directly involved with the selection of leaders and Gothic bishops. As late ancient bishop-missionary, Chrysostom had to become a virtual panopticon for the imperial gaze, to ensure the somatography of Theodosius' law runs without fault, and that the delinquent barbarian bodies, animal-like and heretical, might function properly and meaningfully within the empire.

\section{Leaving Constantinople}

The relationship between mission and ethics regarding Chrysostom's mission to the Goths is mainly concerned with the formation of barbarian identity and the government of the other. Since mission in late antiquity was a complex and strategic system of relations interwoven with several social institutions of the ancien regime, delineating the ethical dimension of Chrysostom's activity should also be seen in the context of these social institutions. Mission was inseparable from imperial power concerns. It was primarily influenced by Christian imperial legislation and policies against heresy. In Chrysostom's mission to the Goths, we see intrareligious mission taking place, within a very potent socio- political subtext. After Chrysostom's death, most Goths in Constantinople were still Arians, so his success was limited. It was especially complicated due to the situation with Gainas and the threat of an attack by Tribigild. Moreover, Chrysostom was still entrenched in the classical Graeco-Roman habitus of barbarism, and he was especially strict against the Arians in the city. Despite this, it is remarkable regarding Chrysostom, that we find somewhat of a rare hybrid in the context of late antiquity, namely the bishop-missionary. Chrysostom was also involved with missionary activity in the near east as far as Lebanon. Chrysostom's mission to the Goths ended in their expulsion from Constantinople after the Gainas affair, a socio-symbolic and historical scar on the reputation of the Christian empire.

\section{Afterword}

In the light of the theme of this volume, 'Mission and Ethics', I aim to briefly end this study with a rather normative question. Considering what has been seen in this study regarding Chrysostom's mission to the Goths, what can we learn from this to understand the relationship between history, ethics and mission in our contemporary context? I cannot observe, in the context of mission in early Christianity and late antiquity, any exemplary value that is not in our own period. But this is not really the issue. The issue is whether there could be some continuity between history, ethics and mission. On a historical-theoretical level, I find it difficult to delineate any relation of the interdependence of these three discursive formations between antiquity and (post-) modernity. Rather than relation, it simply appears to be historical coagulation. The main problem is that the concepts of history, ethics and mission, as we understand them, were totally different in the period of antiquity. What is possible however is to historically relate to ethical experience (in terms of mission) and its history, rather than ethics as a discursive field in itself. One such example from this context is that of identity formation. The construction of the monstrous and heretical barbarian, as the ideal evangelisible other comes into question. The construction, government and care of the other are very relevant ethical issues in missiology. As an ancient historian, I am hardly able to suggest a new missiological model. I would rather suggest that any missiological model should be based on a responsible construction of the other in negotiation with the self, in terms of their existence among institutions that influence and shape them. Heterology is unavoidable, and in some instances, quite necessary. It would feature quite prominently if one were to attempt to write a 'history of mission'. Wood's article may provide a good trajectory for reflecting on this question since he relates the barbarian or Roman discourse to contemporary historical issues. A history of mission is in essence a history of the interaction with the other. It is a matter of perspective. For example, Foucault (2003:63-64) has given attention to the new historico-political discourse of Henri Comte de Boulainvilliers in the late 1720s, in which the État de la France was understood as the (vengeful) late Frankish conquest and enslavement of Roman Gaul (see also Wood 2008:63-64). In this manner, as with the column 
of Arcadius, mission and the identity of the other influence historiography. The ethics of mission should be a reflective process of how we should interact with the other, or rather firstly, how do we see ourselves in relation to the other, and what influence does our authoritative scriptural apparatus have in this negotiation? From the missio-ethical experience of late antiquity, it was seen as destructive and xenophobic. I would argue rather for a dialogical approach, not studying the other as object open to evangelisation and/or conquest, but rather to explore the other as symbolic and symbiotic partner of the self in the negotiation of identity, and to exhibit a suspicious awareness of the institutional influence (such as the state, church, et cetera) on the construction of the identities of both the self and the other.

\section{Acknowledgements \\ Competing interests}

The author declares that he has no financial or personal relationship(s) which may have inappropriately influenced him in writing this article.

\section{References}

Batiffol, P., 1899, 'De quelques homélies de s. Jean Chrysostome et de la version gothique des écritures', Revue Biblique 8, 566-572.

Becatti, G., 1960, La colonna coclide istoriata: Problemi storici, iconografici, stilistici, L'Erma di Bretschneider, Rome. (Studi e Materiali del Museo Dell'Impero Romano).

Berefelt, G., 1968, A study of the winged angel: The origin of the motif, Almquist \& Wiksell, Stockholm.

Bosch, D.J., 1992, Transforming mission: Paradigm shifts in Theology of Mission, Orbis, Maryknoll.

Bowman, G., 2003, 'Beyond othering', American Ethnologist 30(4), 500-501. http:// dx.doi.org/10.1525/ae.2003.30.4.500

Brown, P.R.L., 1981, The cult of the saints: Its rise and function in Latin Christianity, University of Chicago Press, Chicago. (Haskell Lectures on the History of Religions, no. 13).

Calo Levi, A., 1952, Barbarians on Roman imperial coins and sculpture, The American Numismatic Society, New York. (Numismatic Notes and Monographs).

Canales, M.K., 2000, 'Othering: Toward an understanding of difference', Advances in Nursing Science 22(4), 16-31.

Clark, G., 1999, 'Translate into Greek: Porphyry of Tyre on the new barbarians', in R. Miles (ed.), Constructing identities in late antiquity, pp. 112-132, Routledge, London.

Clark, G., 2011, 'Augustine and the merciful barbarians', in R.W. Mathisen \& D. Shanzer (eds.), Romans, barbarians, and the transformation of the Roman world: Cultura interaction and the creation of identity in late antiquity, pp. 33-54, Ashgate, Farnham.

Dagron, G., 1974, Naissance d'une capitale: Constantinople et ses institutions de 330 à 451, Presses Universitaires de France, Paris. (Bibliothèque Byzantine Études).

Daly, L.J., 1972, 'The mandarin and the barbarian: The response of Themistius to the Gothic challenge', Historia: Zeitschrift für Alte Geschichte 21(2), 351-379.

Dauge, Y-A., 1981, La barbare: Recherches sur la conception Romaine de la barbarie et de la civilisation, Latomus, Brussels.

De Certeau, M., 1984, The practice of everyday life, transl. S. Rendall, University of California Press, Berkeley.

De Certeau, M., 1986, Heterologies: Discourse on the other, transl. B. Massumi, University of Minnesota Press, Minneapolis.

Durliat, J. 1997, 'Cité, impôt et intégration des barbares', in W. Pohl (ed.), Kingdoms of empire: The integration of barbarians in late antiquity, pp. 153-180, Brill, Leiden.

Foucault, M., 1961, Madness and civilization, transl. R. Howard, Routledge, London.

Foucault, M., 1986, The history of sexuality: The care of the self, transl. R. Hurley, Vintage, New York.

Foucault, M., 1988, 'Technologies of the self', in L.H. Martin, H. Gutman \& P.H. Hutton (eds.), Technologies of the self: A seminar with Michel Foucault, pp. 16-49, University of Massachusetts Press, Boston.

Foucault, M., 1994, 'The abnormals', in P. Rabinow (ed.), Ethics: The essential works of Foucault 1954-1984, vol. 1, transl. R. Hurley et al., pp. 51-58, Penguin, London.

Foucault, M., 2003, '21 January 1976', in M. Bertani \& A. Fontana (eds.), Society must be defended: Lectures at the Collège de France, 1975-1976, transl. D. Macey, pp. 43-64, Penguin, London.
Foucault, M., 2007, '8 February 1978', in M. Senellart (ed.), Security, territory, population: Lectures at the Collège de France, 1977-1978, transl. G. Burchell, pp. population: Lectures at the College de France

Foucault, M., 2010, '12 January 1983: Second hour', in F. Gros (ed.), The government of the self and others: Lectures at the Collège de France, 1982-1983, transl. G. Burchell, pp. 61-74, Palgrave Macmillan, Hampshire.

González Blanco, A., 1978, 'S. Juan Crisostomo ante el problema barbaro: dimensiones políticas del universalismo evangelico', Miscelánea comillas: Revista de studios históricos 36, 263-299.

Grigg, R., 1977, "'Symphōnian aeidō tēs basileias": An image of imperial harmony on the base of the column of Arcadius', The Art Bulletin 59(4), 469-482. http://dx.doi. org/10.2307/3049702

Gruen, E.S., 2011, Rethinking the other in antiquity, Princeton University Press, Princeton.

Hall, E., 1991, Inventing the barbarian: Greek self-definition through tragedy, Oxford University Press, Oxford.

Heather, P., 1986, 'The crossing of the Danube and the Gothic conversion', Greek, Roman, and Byzantine Studies 27, 289-318.

Heather, P., 1991, The Goths and the Romans, Oxford University Press, Oxford.

Heather, P., 1996, The Goths, The Peoples of Europe, Blackwell, Oxford.

Heather, P., 1999, 'The barbarian in late antiquity: Image, reality, and transformation', in R. Miles (ed.), Constructing identities in late antiquity, pp. 234-258, Routledge, London.

Hedeager, L., 1987, 'Empire, frontier and the barbarian hinterland: Rome and northern Europe from AD 1-400', in M.J. Rowlands, M.T. Larsen \& K. Kristiansen (eds.), Centre and periphery in the ancient world, pp. 125-140, Cambridge University Press, Cambridge.

Kelly, J.N.D., 1995, Golden mouth: The story of John Chrysostom - Ascetic, preacher, bishop, Cornell University Press, New York.

Kelly, J., 2006, 'The column of Arcadius: Reflections of a Roman narrative tradition', Byzantina Australiensia 16, 258-265.

Kollwitz, J., 1941, Oströmische Plastik der Theodosianischen Zeit, De Gruyter, Berlin.

Lianeri, A. \& Zajko, V. (eds.), 2009, Translation and the classic: Identity as change in the history of culture, Oxford University Press, Oxford.

Liebeschuetz, J.H.W.G., 1990, Barbarians and bishops: Army, church, and state in the age of Arcadius and Chrysostom, Clarendon, Oxford.

Liebeschuetz, J.H.W.G., 2011, Ambrose and John Chrysostom: Clerics between desert and empire, Oxford University Press, Oxford.

Magdalino, P., 1996, Constantinople médiévale: Études sur l'évolution des structures urbaines, De Boccard, Paris. (Travaux et mémoires du centre de recherche $d^{\prime}$ histoire et civilisation de Byzance monographies).

Mango, C., 1978, 'The date of the Studius Basilica at Istanbul', Byzantine and Modern Greek Studies 4, 115-122.

Mathisen, R.W., 2006, 'Violent behaviour and the construction of barbarian identity in late antiquity', in H.A. Drake (ed.), Violence in late antiquity: Perceptions and practices, pp. 27-36, Ashgate, Aldershot.

Mathisen, R.W., 2009, 'Provinciales, gentiles, and marriages between Romans and barbarians in the late Roman Empire', Journal of Roman Studies 99, 140-155. http://dx.doi.org/10.3815/007543509789745025

Mathisen, R.W., 2011, 'Catalogues of barbarians in late antiquity', in R.W. Mathisen \& D. Shanzer (eds.), Romans, barbarians, and the transformation of the Roman world: Cultural interaction and the creation of identity in late antiquity, pp. 17-32, Ashgate, Farnham.

Mattingly, D.J., 2011, Imperialism, power, and identity: Experiencing the Roman Empire, Princeton University Press, Princeton.

Maxwell, J.L., 2006, Christianization and communication in late antiquity: John Chrysostom and his congregation in Antioch, Cambridge University Press, Chrysostom and his congregation in Antioch, Cambridge
Cambridge. http://dx.doi.org/10.1017/CBO9780511482854

Mayer, W., 2008, 'Homiletics', in S. Ashbrook Harvey \& D.G. Hunter (eds.), The Oxford Handbook of Early Christian Studies, pp. 565-583, Oxford University Press, Oxford. http://dx.doi.org/10.1093/oxfordhb/9780199271566.003.0028

Mayer, W. \& Allen, P., 1999, John Chrysostom, Routledge, London. (The Early Church Fathers).

Munson, R., 2005, Black doves speak: Herodotus and the languages of the barbarians, Centre for Hellenic Studies, Washington DC.

Nasrallah, L.S., 2011, Christian responses to Roman art and architecture: The secondcentury amid the spaces of empire, Cambridge University Press, Cambridge.

Pamuk, O., 2004, Istanbul: Memories and the city, Vintage, New York.

Parker, H.N., 1997, 'The teratogenic grid', in J.P. Hallett \& M.B. Skinner (eds.), Roman sexualities, pp. 47-65, Princeton University Press, Princeton.

Pavan, M., 1964, La politica Gotica di Teodosio nella pubblicistica del suo tempo, Bretschneider, Rome.

Peers, G., 2001, Subtle bodies: Representing angels in Byzantium, University of California Press, Berkeley.

Penella, R. J., 2000, The private orations of Themistius, University of California Press, Berkeley.

Peters, E. (ed.), 1980, Heresy and authority in medieval Europe, University of Pennsylvania Press, Philadelphia.

Pohl, W., 1997, 'Introduction: The empire and the integration of barbarians', in W. Pohl (ed.), Kingdoms of empire: The integration of barbarians in late antiquity, pp. 1-12, Brill, Leiden. 
Pohl, W., 2006, 'Perceptions of barbarian violence', in H.A. Drake (ed.), Violence in late antiquity: Perceptions and practices, pp. 15-26, Ashgate, Aldershot.

Richlin, A., 2009, 'Sexuality in the Roman Empire', in D.S. Potter (ed.), A companion to the Roman Empire, pp. 327-353, Blackwell, Oxford. (Blackwell Companions to the Ancient World).

Riggins, S.H., 1997, 'The rhetoric of othering', in S.H. Riggins (ed.), The language and politics of exclusion: Others in discourse, pp. 1-30, Sage, Thousand Oaks.

Rohrbacher, D., 2002, The historians of late antiquity, Routledge, London. http:// dx.doi.org/10.4324/9780203458754

Schott, J.M., 2008, Christianity, empire and the making of religion in late antiquity, University of Pennsylvania Press, Philadelphia.

Schwarcz, A., 1999, 'Cult and religion among the Tervingi and the Visigoths and their conversion to Christianity', in P. Heather (ed.), The Visigoths from the migration period to the seventh century, pp. 447-472, Boydell, Woodbridge.

Shepardson, C.C., 2007, 'Controlling contested places: John Chrysostom's Adversus Iudaeos homilies and the spatial politics of religious controversy', Journal of Early Christian Studies 15(4), 483-516. http://dx.doi.org/10.1353/earl.2007.0060

Sibiescu, V.G., 1973, 'L'activité missionaire de saint Jean Chrysostom parmi les Goths - VIIle Homélie', Glasul Bisericii 32, 375-388.

Stanfill, J., 2011, 'John Chrysostom's Gothic parish and the politics of space', paper presented at the Sixteenth International Conference on Patristic Studies, University of Oxford, Oxford, 08-12 August.
Telfer, W., 1950, 'Paul of Constantinople', Harvard Theological Review 43(1), 30-92. http://dx.doi.org/10.1017/S0017816000024366

Thompson, E.A., 1966, The Visigoths in the time of Ulfila, Duckworth, London.

Van Houtum, H. \& Van Naerssen, T., 2002, 'Bordering, ordering and othering', Tijdschrift voor Economische en Sociale Geografie 93(2), 125-136. http://dx.doi. org/10.1111/1467-9663.00189

Walters, J., 1997, 'Invading the Roman body: Manliness and impenetrability in Roman thought', in J.P. Hallett \& M.B. Skinner (eds.), Roman sexualities, pp. 29-46, Princeton University Press, Princeton.

Weyman, C., 1894, 'Omonoia', Hermes 29, 623-637.

Wiedemann, T.E.C., 1986, 'Between men and beasts: Barbarians in Ammianus Marcellinus', in I. S. Moxon, J.D. Smart \& A.J. Woodman (eds.), Past perspectives: Studies in Greek and Roman historical writing, pp. 135-154, Cambridge University Press, Cambridge.

Wolfram, H. \& Dunlap. T.J., 1990, History of the Goths, University of California Press, Berkeley.

Wood, I., 2008, 'Barbarians, historians, and the construction of national identities', Journal of Late Antiquity 1(1), 61-81. http://dx.doi.org/10.1353/jla.0.0007

Woolf, G., 2011, Tales of the barbarians: Ethnography and empire in the Roman west, Blackwell Bristol Lectures on Greece, Rome and the Classical Tradition, Wiley-Blackwell, Chichester. (Blackwell Bristol Lectures on Greece, Rome and the Classical Tradition) 